\title{
Diagnosing recent CO emissions and ozone evolution in East Asia using coordinated surface observations, adjoint inverse modeling, and MOPITT satellite data
}

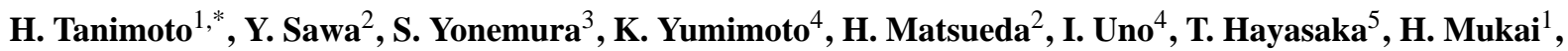 \\ Y. Tohjima ${ }^{1}$, K. Tsuboi ${ }^{6}$, and L. Zhang ${ }^{7}$ \\ ${ }^{1}$ National Institute for Environmental Studies, Tsukuba, Japan \\ ${ }^{2}$ Meteorological Research Institute, Tsukuba, Japan \\ ${ }^{3}$ National Institute for Agro-Environmental Sciences, Tsukuba, Japan \\ ${ }^{4}$ Kyushu University, Fukuoka, Japan \\ ${ }^{5}$ Research Institute for Humanity and Nature, Kyoto, Japan \\ ${ }^{6}$ Japan Meteorological Agency, Tokyo, Japan \\ ${ }^{7}$ Harvard University, Cambridge, MA, USA \\ *also at: Harvard University, Cambridge, MA, USA
}

Received: 6 December 2007 - Published in Atmos. Chem. Phys. Discuss.: 20 February 2008

Revised: 25 June 2008 - Accepted: 26 June 2008 - Published: 22 July 2008

\begin{abstract}
Simultaneous ground-based measurements of ozone $\left(\mathrm{O}_{3}\right)$ and carbon monoxide $(\mathrm{CO})$ were conducted in March 2005 as part of the East Asian Regional Experiment (EAREX) 2005 under the umbrella of the Atmospheric Brown Clouds $(\mathrm{ABC})$ project. Multiple air quality monitoring networks were integrated by performing intercomparison of individual calibration standards and measurement techniques to ensure comparability of ambient measurements, along with providing consistently high time-resolution measurements of $\mathrm{O}_{3}$ and $\mathrm{CO}$ at the surface sites in East Asia. Ambient data collected from eight surface stations were compared with simulation results obtained by a regional chemistry transport model to infer recent changes in $\mathrm{CO}$ emissions from East Asia. Our inverse estimates of the $\mathrm{CO}$ emissions from China up to 2005 suggested an increase of $16 \%$ since 2001, in good agreement with the recent MOPITT satellite observations and the bottom-up estimates up to 2006. The $\mathrm{O}_{3}$ enhancement relative to $\mathrm{CO}$ in continental pollution plumes traversed in the boundary layer were examined as a function of transport time from the Asian continent to the western Pacific Ocean. The observed $\Delta \mathrm{O}_{3} / \Delta \mathrm{CO}$ ratios show increasing tendency during eastward transport events due likely to enroute photochemical $\mathrm{O}_{3}$ formation, suggesting that East Asia is an important $\mathrm{O}_{3}$ source region during spring.
\end{abstract}

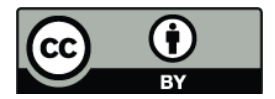

Correspondence to: $\mathrm{H}$. Tanimoto (tanimoto@nies.go.jp)

\section{Introduction}

East Asia is one of the large source regions of anthropogenic pollutants to the global atmosphere. Rapidly developing economic growth increases emissions of anthropogenic pollutants from a variety of emission sources including industry, transportation, and power plant sectors. Gaseous pollutants and aerosols emitted from these sources have local and regional, as well as substantial global impacts due to longrange transport around the northern hemisphere. Changes in land-use due to expanding residential areas can also increase emissions of dust aerosols and nitrogen oxides $\left(\mathrm{NO}_{\mathrm{x}}\right)$. Emissions of air pollutants from East Asia are estimated to have rapidly increased during the past decades, in contrast to those from Europe and North America, which show decreasing and stabilized trends, respectively (Akimoto, 2003).

Changes in the emissions of pollutants to the atmosphere may have become more dramatic since 2000. Space-based observations of nitrogen dioxides $\left(\mathrm{NO}_{2}\right)$ from GOME and SCIAMACHY satellite-borne sensors have revealed a rapid increase of tropospheric $\mathrm{NO}_{2}$ columns over China since 2000 , possibly as a consequence of increasing anthropogenic emissions (Richter et al., 2005). In contrast, bottom-up estimates of $\mathrm{NO}_{\mathrm{x}}$ emissions inventory show an increase not as large as those obtained from the satellite measurements. Indeed, there are substantial discrepancies in the trend between the satellite $\mathrm{NO}_{2}$ measurements and the bottom-up $\mathrm{NO}_{\mathrm{x}}$ emissions inventory (Akimoto et al., 2006). Accurate estimates and prompt updates of the emissions of air

Published by Copernicus Publications on behalf of the European Geosciences Union. 
pollutants are thus important to assess the resulting impacts on temporal evolution of primary pollutants and secondary species (e.g., photochemical $\mathrm{O}_{3}$ formation) in regional and hemispheric background levels.

It is however difficult to accurately follow the temporal variation in the emission field from the bottom-up emission estimates because of their inherent uncertainty and time lag in the update of statistics published by national and/or local governments. Some emission sectors have large temporal variability. For example, carbon monoxide (CO) is primarily emitted by combustion of coal, oil, biofuels, and biomass in various sources including power plants, industries, vehicles, agricultural burning (which has strong seasonal variations) and forest fires (which have inter-annual variations). Hence it is challenging to estimate emissions of $\mathrm{CO}$ for regions where multiple emission sectors contribute to a combined net $\mathrm{CO}$ concentration field. To overcome such difficulties, observations of chemical species, either in situ measurements or satellite observations, have been used to provide constraints on the strength and spatial distributions of their emissions. Transport and Chemical Evolution over the Pacific (TRACEP) was conducted, in the spring of 2001, by the National Aeronautical Space Administration (NASA) to address the issue of pollution emissions from Asia, by integrating in situ measurements by aircrafts, satellite observations from space, and chemistry transport models (Jacob et al., 2003).

Several inversion studies to estimate $\mathrm{CO}$ emissions from East Asia during TRACE-P revealed that the $\mathrm{CO}$ emission inventory used as a priori emissions for China (Streets et al., 2003a) was significantly underestimated $(\sim 50 \%)$ (Palmer et al., 2003; Heald et al., 2004; Wang et al., 2004; Allen et al., 2004; Carmichael et al., 2003). After TRACE-P Streets et al. (2006) improved their a priori CO emissions inventory for China based on the model analysis of $\mathrm{CO}$ observed during the TRACE-P campaign. They examined various causes for the large discrepancy between the bottom-up and topdown estimates, and found that the $\mathrm{CO}$ emissions from cement kilns, brick kilns, and the iron and steel industry were underestimated. The updated anthropogenic $\mathrm{CO}$ emissions from China in 2001 are $142 \mathrm{Tg}, 42 \%$ higher than the a priori emissions used during TRACE-P in 2000. Since industrial activities and the energy consumption in China are thought to have increased since 2001, great attention is paid to possible changes in the anthropogenic emissions of air pollutants from China, and the resulting impacts on secondary species including photochemical $\mathrm{O}_{3}$ formation.

In this paper we mainly focus on the following questions.

- Can we constrain regional sources for CO in 2005 by exploiting multiple surface observations in an inverse calculation? What is the growth of $\mathrm{CO}$ emission from East Asia since 2001?

- Can we identify the causes of the observed $\mathrm{O}_{3}-\mathrm{CO}$ ratio enhancement events? Is this quantitatively related to the transport timescale of continental pollutants?
- Can the model explain the observed $\mathrm{O}_{3}-\mathrm{CO}$ correlation well? What are the spatial patterns of the $\mathrm{O}_{3}-\mathrm{CO}$ relationship?

We use hourly values of $\mathrm{O}_{3}$ and $\mathrm{CO}$ simultaneously recorded at eight ground-based stations, and a regional transport model that incorporates the chemistry of these species. A four-dimensional adjoint inverse model developed for East Asia is also used to improve the $\mathrm{CO}$ emissions inventory and to infer the spatial distribution of $\mathrm{CO}$ emission over China up to 2005. The growth in the $\mathrm{CO}$ emission from China since 2001 is discussed with the help of satellite-derived trends and recently updated bottom-up estimates. We select, from the observed temporal variations of $\mathrm{O}_{3}$ and $\mathrm{CO}$, three pollution events, which were well characterized in terms of meteorological mechanisms and the $\mathrm{CO}$ source-receptor relationship in our previous paper (Sawa et al., 2007). We show simulated results of the regional spatial pattern of the boundary layer $\mathrm{O}_{3}-\mathrm{CO}$ correlation, which are often referred to as an indicator of the photochemical $\mathrm{O}_{3}$ processing in continental outflows (Parrish et al., 1993, 1998). Ambient data off the coast of the Asian continent obtained during early spring are suitable for evaluating pollution emissions from the Asian continent, since transport from the upwind source regions to the western North Pacific occurs most effectively during this time of year.

\section{Coordinated ground-based observations}

\subsection{Integration of networks}

The EAREX 2005 campaign was conducted from the end of February to early April 2005 as a part of international intercomparison experiments. Measurements of $\mathrm{CO}$ and $\mathrm{O}_{3}$ were undertaken with collaboration of four Asian research groups from Japan, Korea, Hong Kong and Taiwan. During the campaign, we observed $\mathrm{CO}$ and $\mathrm{O}_{3}$ mixing ratios at Gosan station $\left(33^{\circ} 17^{\prime} \mathrm{N}, 126^{\circ} 10^{\prime} \mathrm{E}\right)$ located at Jeju Island in Korea. The Gosan station is one of the UNEP/ABC supersites operated by the Meteorological Research Institute (METRI) of the Korea Meteorological Administration (KMA). Results from the intercomparison experiment in the EAREX 2005 showed that the ambient air measurements of $\mathrm{CO}$ and $\mathrm{O}_{3}$ from the different research groups at Gosan agreed with each other fairly well (Tanimoto et al., 2007a, b). In order to investigate the spatio-temporal variations of $\mathrm{CO}$ and $\mathrm{O}_{3}$, the data obtained at seven Japanese stations were compared to those at Gosan for the same period of time.

Figure 1 shows the geographical distribution of all the stations used in the present study. The stations are suitably distributed for characterizing the spreading air pollution from the Asian continent over the western North Pacific region between $43^{\circ} \mathrm{N}$ to $24^{\circ} \mathrm{N}$. All these 8 surface stations are located generally in rural to remote regions where influences of local emissions are negligible. 
The Fukuejima station $\left(32^{\circ} 45^{\prime} \mathrm{N}, 128^{\circ} 41^{\prime} \mathrm{E}\right)$ located west of Japan is closest to the Gosan station, while the AmamiOshima station $\left(28^{\circ} 26^{\prime} \mathrm{N}, 129^{\circ} 41^{\prime} \mathrm{E}\right)$ is located to the south of Gosan. At these two island stations, $\mathrm{CO}$ and $\mathrm{O}_{3}$ measurements were collaboratively performed by NIAES, the Research Institute for Humanity and Nature (RIHN), and the Center for Climate System Research (CCSR) under the aerosol research programs of SKYNET and the National Institute for Environmental Studies (NIES) LidarNet. The Japan Meteorological Agency (JMA) has been monitoring $\mathrm{CO}, \mathrm{O}_{3}$ and other trace gases at Yonagunijima $\left(24^{\circ} 28^{\prime} \mathrm{N}\right.$, $\left.123^{\circ} 01^{\prime} \mathrm{E}\right)$, Minamitorishima $\left(24^{\circ} 17^{\prime} \mathrm{N}, 153^{\circ} 39^{\prime} \mathrm{E}\right)$, and Ryori $\left(39^{\circ} 02^{\prime} \mathrm{N}, 141^{\circ} 49^{\prime} \mathrm{E}\right)$ for the Global Atmosphere Watch programme of the World Meteorological Organization (WMO/GAW). Minamitorishima is located the farthest from the Asian continent (about $2000 \mathrm{~km}$ southeast of Tokyo). The observational data at these JMA stations are available on the web site of the World Data Center for Greenhouse Gases (WDCGG) operated by JMA (http://gaw.kishou.go.jp/ wdcgg.html). Trace gas measurements at Cape Ochi-ishi $\left(43^{\circ} 09^{\prime} \mathrm{N}, 145^{\circ} 30^{\prime} \mathrm{E}\right)$ and Hateruma $\left(24^{\circ} 3^{\prime} \mathrm{N}, 123^{\circ} 48^{\prime} \mathrm{E}\right)$, which are located at the northernmost and southernmost positions in the network, respectively, are conducted by NIES for the Center for Global Environmental Research (CGER) monitoring program (e.g., Tohjima et al., 2002).

Also shown in Fig. 1 are the 5-day forward trajectories starting from $1000 \mathrm{~m}$ at Gosan during the observation period in March 2005. Forward trajectories from Gosan are widely scattered from north to south. Northward trajectories are generally confined to the 2 to $5 \mathrm{~km}$ altitude layer, with some reaching Kamchatka Peninsula and even Aleutian Islands after passing over Ryori and Cape Ochi-ishi stations. Nearly all of the southward trajectories traverse within the bottom 1-km layer of the troposphere, passing over Fukuejima, Amami-Oshima, Yonagunijima, and Hateruma, with some reaching Southeast Asia including Philippine Islands. For eastward transport, many trajectories stay within the bottom 1-km layer, some reaching Minamitorishima during the 5-day transport. These transport patterns portray Gosan as one of the "export windows" of the continental pollution outflow to the western North Pacific Rim (Wong et al., 2007), and thus enabling us to interpret temporal variations of $\mathrm{O}_{3}$ and $\mathrm{CO}$ observed at other stations downwind in terms of ambient measurements made at Gosan. It is important to keep in mind that the northbound transport occurs often in the free troposphere, while much of the southbound and eastbound transport takes place within the marine boundary layer. We will see in the following sections how this spatial difference in the transport pattern is reflected in the observed temporal variations of $\mathrm{O}_{3}$ and $\mathrm{CO}$ at each station.

\subsection{Instruments and data comparability}

$\mathrm{CO}$ mixing ratios at Gosan were measured using a nondispersive infrared analyzer (NDIR, APMA-360 model,

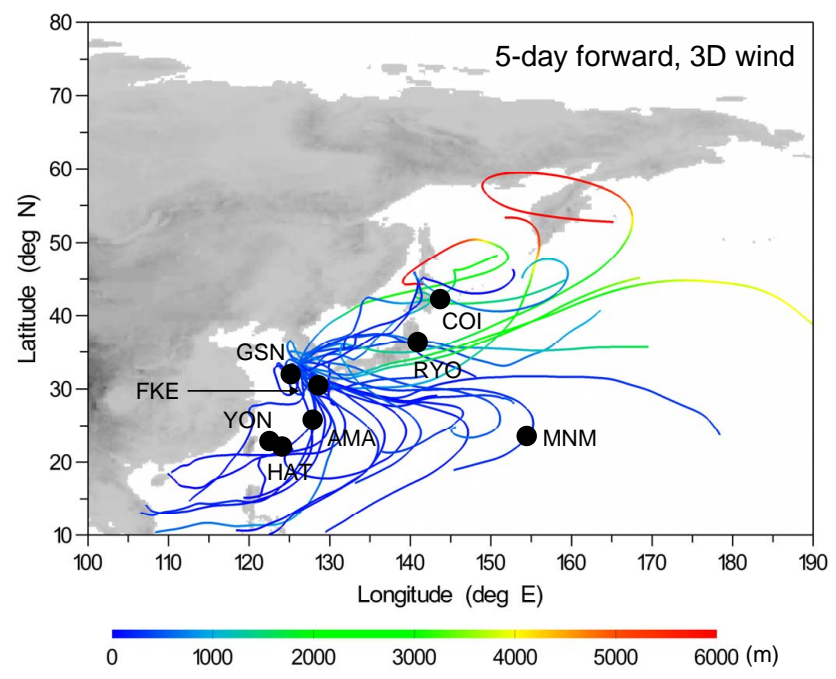

Fig. 1. Geographical locations of the ground-based stations, along with 5-day forward trajectories starting from Gosan, Jeju Island during the EAREX 2005 campaign period in March, 2005 (COI, Cape Ochi-ishi; RYO, Ryori; GSN, Gosan; FKE, Fukuejima; AMA, Amami Oshima; YON, Yonagunijima; HAT, Hateruma; MNM, Minamitorishima). Trajectory altitudes are color-coded. Topographic elevations are expressed by different shades of gray.

Horiba Co. Ltd., Japan). The NDIR analyzer was regularly calibrated using a $\mathrm{CO}$-free air and $\mathrm{CO}$ standard gas with a mixing ratio of about $1 \mathrm{ppmv}$. The $\mathrm{CO}$-free air was produced by passing ambient air through a catalytic oxidation column packed with Sofnocat (514, Molecular Products Ltd., UK) to completely remove $\mathrm{CO}$ in the sample air. Overall uncertainty of the NDIR system was estimated to be less than $20 \mathrm{ppbv}$. Measurements of $\mathrm{CO}$ at Fukuejima and Amami-Oshima stations were made by the gas filter correlation method (GFC) using commercially available $\mathrm{CO}$ analyzers (model 48C, Thermo Electron Inc., USA) combined with zero-air generators of CO-free air (model 111, Thermo Electron Inc., USA). The GFC analyzers at both stations were regularly calibrated using one $\mathrm{CO}$ standard gas of about $1 \mathrm{ppmv}$. The overall uncertainty of the GFC method was estimated to be about 10 ppbv based on the comparison with the $\mathrm{GC} / \mathrm{HgO}$ method at NIAES. NDIR analyzers (GA-360S model, Horiba Co. Ltd., Japan) were deployed by JMA for CO measurements at their three WMO/GAW stations (Watanabe et al., 2000). At Cape Ochi-ishi and Hateruma, the $\mathrm{CO}$ data were obtained by the GC/HgO (RGD2, Trace Analytical Co. Ltd., USA) method, primarily based on the NIES calibration scale derived from gravimetric $\mathrm{CO}$ standard gases.

Measurements of $\mathrm{O}_{3}$ at these eight stations were based on the same principle. Ultraviolet absorption analyzers, which are commercially available from various manufactures, were deployed. At Gosan, Cape Ochi-ishi, and Hateruma a singlecell instruments (1150 model, Dylec Co. Ltd., Japan) were used. Similar instruments (1006AHJ model, Dasibi Co. Ltd., 
USA) were used at Fukuejima and Amami-Oshima. For Yonagunijima, Minamitorishima, and Ryori, JMA deployed ozone analyzers from a different manufacture (EG2001F model, Ebara Jitsugyo Co., Ltd., Japan). All of these instruments require a sample airflow of about $1.5 \mathrm{~L} / \mathrm{min}$. Correction for temperature and pressure was applied. The overall uncertainty was typically about $1 \%$.

Since the ambient data used in this study were obtained with instruments and calibration scales independently maintained by various individual groups, we made intercomparison of standards for different trace gases. Details of the intercomparison activities are found elsewhere (Tanimoto et al., 2007a, b). Briefly, we used the gravimetric scale maintained by MRI as our primary reference. The $\mathrm{CO}$ gas standards at Gosan were calibrated before and after the observations using 5 gravimetric standard gases prepared as a MRI primary scale (Matsueda et al., 1998). The MRI primary standard scale used at Gosan station was applied to the gas standards used at Fukuejima and Amami-Oshima in order to produce a consistent dataset. A previous intercomparison of ambient CO measurements between JMA and MRI showed a systematic difference of about 10 ppbv mainly due to the standard gas scale. Since this difference was relatively small compared to the large analytical error resulting from the NDIR method, CO values from the JMA system were not corrected. We concluded that the hourly $\mathrm{CO}$ data from all of the stations used in this study were comparable and consistent to within an overall uncertainty of about 20-30 ppbv. Although a direct intercomparison between MRI and the National Oceanic and Atmospheric Administration/Global Monitoring Division (NOAA/GMD, former NOAA/CMDL) has not been performed, an audit for $\mathrm{CO}$ measurements at the JMA stations made by the Swiss Federal Laboratories for Materials Testing and Research (EMPA) in the framework of the WMO/GAW programme suggested good agreement between the JMA and EMPA standards (Zellweger et al., 2005). Since gas standards used by EMPA are traceable to NOAA/GMD, these results indirectly suggest reasonable consistency between the MRI and NOAA/GMD scales. For $\mathrm{O}_{3}$, the Standard Reference Photometer (SRP) built by the National Institute of Standards and Technology (NIST) and maintained by NIES was used as a reference (Tanimoto et al., 2006). The $\mathrm{O}_{3}$ monitors at Gosan, Cape Ochi-ishi, and Hateruma were directly calibrated by SRP at NIES, and those at Fukuejima and Amami-Oshima were calibrated by means of a secondary standard. Quality assurance and quality control for the $\mathrm{O}_{3}$ instruments operated at the JMA stations were periodically made under the umbrella of WMO/GAW programme. These instruments are referenced to the same type of SRP built by NIST. Overall agreement for $\mathrm{O}_{3}$ instruments used in this study is within $\pm 2 \%$.

\section{Regional chemistry transport models}

\subsection{Forward modeling}

A three-dimensional regional-scale chemistry transport model (CTM) used in this study has been developed jointly by Kyushu University and NIES (Tanimoto et al., 2005; Uno et al., 2007) and is based on the Models-3 Community Multi-scale Air Quality (CMAQ) modeling system released by the United States-Environmental Protection Agency. In the present study, the model was driven by meteorological fields generated by the Regional Atmospheric Modeling System (RAMS). The horizontal and vertical resolutions were fixed to $80 \mathrm{~km}$ and 14 layers (up to $23 \mathrm{~km}$ ), respectively. The SAPRC-99 scheme was applied for gas-phase chemistry. A global chemistry transport model was used to generate monthly averaged lateral boundary conditions for CMAQ (Tanimoto et al., 2005).

The emissions inventory incorporated into the model was based on the Regional Emission inventory in Asia (REAS) (version 1.1) for the period 2003 (Ohara et al., 2007). Emissions of sulfur dioxides $\left(\mathrm{SO}_{2}\right), \mathrm{NO}_{\mathrm{x}}, \mathrm{CO}$, non-methane volatile organic compounds (NMVOC), black carbon (BC), and organic carbon (OC) from fuel combustion and industrial sources were implemented. Biomass burning sources developed by Streets et al. (2003a, b) were used for the CMAQ simulation.

\subsection{Adjoint inverse modeling}

In this study, RAMS/CTM-4DVAR (Yumimoto and Uno, 2006; Yumimoto et al., 2007) was employed for an inverse modeling of CO emissions. RAMS/CTM-4DVAR is built on a meso-scale meteorological model RAMS (version 4.3, Pielke et al. (1992)) using its optional scalar transport options. The 4DVAR system consists of a forward CTM, its adjoint model, and an optimization process. Details of the method have been presented in Yumimoto and Uno (2006), so we only describe aspects of the method relevant to this study.

The model domain was centered at $25^{\circ} \mathrm{N}$ and $115^{\circ} \mathrm{E}$ on a rotated polar stereo-graphics system encompassing East Asia (see Fig. 5), with a horizontal resolution of $80 \mathrm{~km}$ and 23 vertical levels (the top level is $23 \mathrm{~km}$; stretching from $150 \mathrm{~m}$ at the surface to $1800 \mathrm{~m}$ at the top). The a priori gridded CO emission inventory was based on Streets et al. (2003a) for 2000, which extended throughout East and Southeast Asia (emissions over Russia were not included) and was evaluated as monthly values with $1^{\circ} \times 1^{\circ}$ resolution.

The assimilation period was from 4 March to 10 April 2005. We used ground-based observations measured from 11 March to 10 April 2005 at 6 observational sites (Gosan, Ryori, Fukuejima, Amami-Oshima, Yonagunijima, and Hateruma, see Fig. 1) to assimilate CO mixing ratios and optimize monthly CO emission over East Asia. Observations at 
Cape Ochi-ishi were used for independent validations. For the lateral boundary condition of the model domain, simple constant $\mathrm{CO}$ boundary inflows (130 ppbv for the northerly inflow, $80 \mathrm{ppbv}$ for the southerly inflow, $90 \mathrm{ppbv}$ for the westerly inflow, and 90 ppbv for the easterly inflow) were used.

\section{Observed and modeled $\mathrm{O}_{3}$ and $\mathrm{CO}$}

\subsection{Observed pollution episodes}

Short-term temporal variations of $\mathrm{O}_{3}$ and $\mathrm{CO}$ observed at all the 8 stations in March 2005 are shown in Fig. 2. Enhanced $\mathrm{CO}$ mixing rations were often observed at Gosan, with some large sharp peaks exceeding $500 \mathrm{ppbv}$. In addition, a number of small CO peaks were also found. The overall $\mathrm{CO}$ variability was large, likely reflecting the downwind location of Gosan from the industrial source regions of the Asian continent. Remarkably, some of these large CO peaks were still observable, with very little change in shape and magnitude, at Japanese stations located in regions relatively close to Gosan (i.e., Fukuejima, Amami-Oshima, Yonagunijima, and Hateruma). At Minamitorishima, located more than $2000 \mathrm{~km}$ off the Asian continent, the CO measurements were characteristically different (with smoother background and smaller anomalies) from those observed at stations upwind (i.e., Gosan, Fukuejima, Amami-Oshima, Yonagunijima, and Hateruma). At two stations located in northern Japan (Ryori and Cape Ochi-ishi), we observed relatively smooth background $\mathrm{CO}$ interrupted by a few small anomalies. For $\mathrm{O}_{3}$, all the stations showed characteristic variations in time, with some of the positive anomalies corresponding well to high $\mathrm{CO}$ episodes. The enhancements of $\mathrm{O}_{3}$ concentration relative to $\mathrm{CO}$ were small at Gosan and Fukuejima, likely due to high variability in the $\mathrm{O}_{3}$ levels caused by mixing of different polluted air masses. Increased $\mathrm{O}_{3}$ concentration events were more identifiable at Amami-Oshima, Yonagunijima, and Hateruma stations. Although the positively anomalous peaks became broader at Minamitorishima, corresponding episodes in $\mathrm{O}_{3}$ and $\mathrm{CO}$ were still observable at the station.

Here we focus on three events observed at Gosan: Event I (DOY 69-71: 10-12 March), Event II (DOY 76-78: 1719 March), and Event III (DOY 81-83: 22-24 March), and explore the evolution of the pollution plumes associated with these events as they were transported within the marine boundary layer to the western North Pacific (DOY = Day of the Year). We chose these 3 events for a detailed examination because the pollution episodes associated with these events retained relatively clear signature during their propagation to stations downwind. Furthermore, transport mechanisms triggered by cold fronts for these episodes were well analyzed with a three-dimensional global transport model in our previous paper (Sawa et al., 2007).
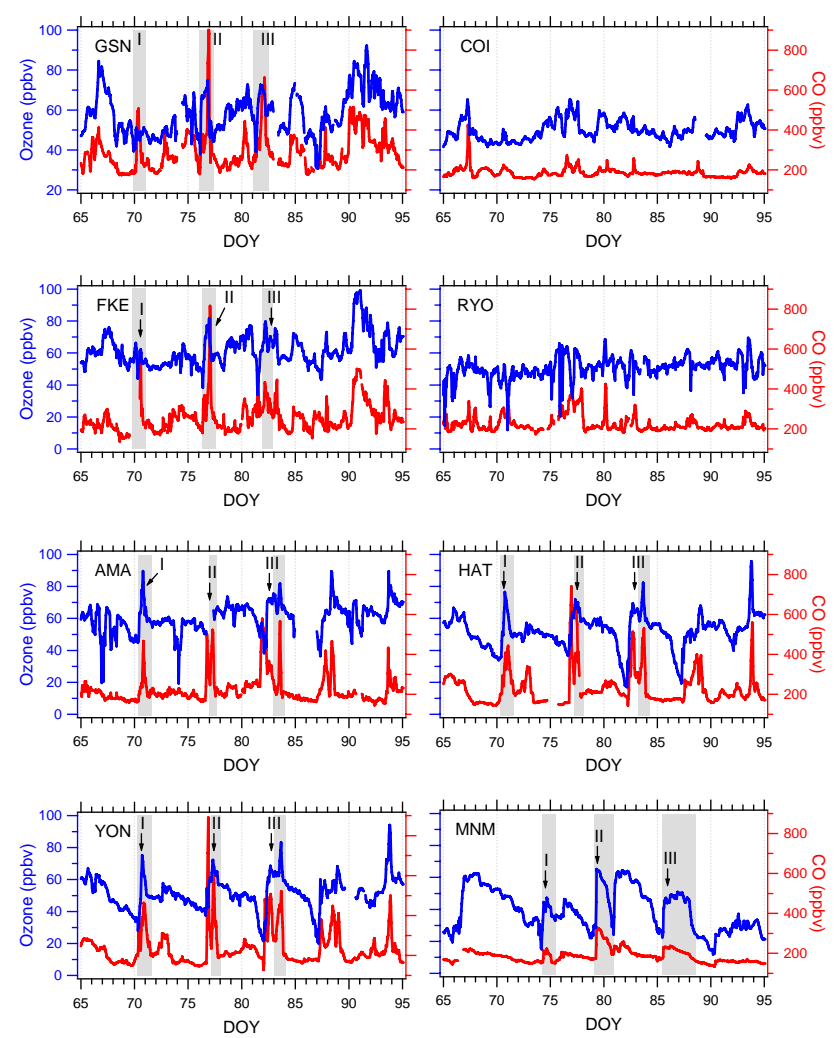

Fig. 2. Observed hourly time series of $\mathrm{O}_{3}$ (blue, left axis) and $\mathrm{CO}$ (orange, right axis) mixing ratios at each station. Three pollution episodes observed are gray-shaded and labeled by the episode number (i.e., I, II, and III). These three episodes were identified and characterized by Sawa et al. (2007). Time units are Local Time (UTC+9).

In Sawa et al. (2007), synoptic weather conditions and transport mechanisms of polluted air masses from the Asian continent to the western Pacific Ocean were analyzed by utilizing $\mathrm{CO}$ as a tracer. They found that the positive $\mathrm{CO}$ anomalies of these events identified above were brought about by the passages of cold fronts associated with eastward migrating cyclonic developments. The polluted air masses exported from the continent were trapped behind the cold fronts and then merged into elongated belts of enriched $\mathrm{CO}$ before spreading over the western North Pacific. Using a global transport model, they were also able to demonstrate that episodic increase in CO observed at Minamitorishima was caused by a long-range transport of pollutants emitted from various regions of East Asia (e.g., China, Korea, Taiwan, Japan).

The episodic events of CO increase observed during 2527 March (DOY 84-86) and 31 March-2 April (DOY 9092) at Gosan are not discussed in this paper since these events were not well characterized by our previous analysis. For these periods, simultaneous CO increases were not detected at Amami-Oshima and Yonagunijima. Meteorological 

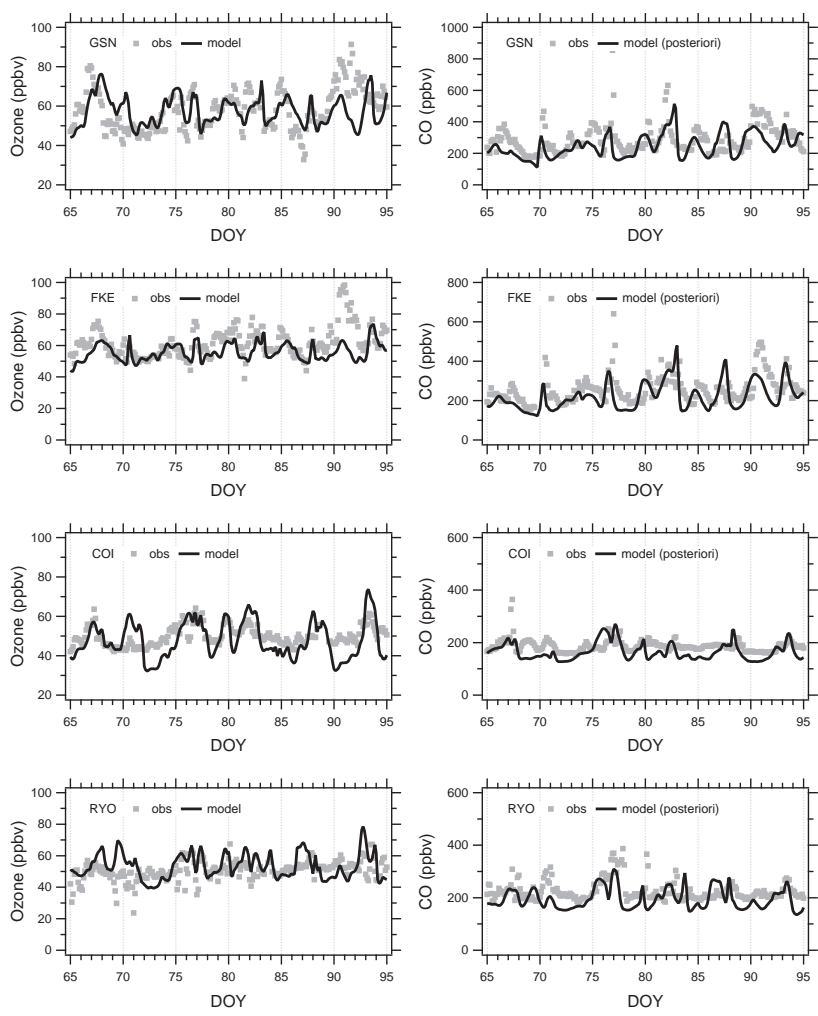

Fig. 3. Comparison of observed (gray circles) and modeled (black lines) 3-hourly time series of $\mathrm{O}_{3}$ and $\mathrm{CO}$ mixing ratios at all stations. Data at Minamitorishima are not shown here because it is out of the model domain. Time units are Local Time (UTC+9).

analysis by Sawa et al. (2007) suggested that these events were not "typical" cases for cold fronts-associated transport from Asian continent to the western Pacific. These pollution events did not reach to Minamitorishima, prohibiting us from exploring $\mathrm{O}_{3}-\mathrm{CO}$ relationships in the same air masses. Hence, we did not analyze these events.

\subsection{Model simulation}

Figure 3 shows comparison of observed and modeled shortterm temporal variations of $\mathrm{O}_{3}$ and $\mathrm{CO}$ for March 2005. The modeled temporal variations for $\mathrm{CO}$ were assimilated by the 4-dimensional adjoint inversion. In general, the levels and variations of $\mathrm{O}_{3}$ observed at all stations were well simulated by the model. Observed $\mathrm{CO}$ values were also reasonably well simulated with improved $\mathrm{CO}$ emissions inventory constrained by the observations obtained in this study. It is well known that the continental air masses from East Asia are often transported by synoptic-scale weather systems. The timing of large episodic spikes in CO observed at AmamiOshima, Yonagunijima, and Hateruma was in particular well reproduced, along with the corresponding increase in $\mathrm{O}_{3}$.

Scatter plots of observed versus modeled mixing ratios of $\mathrm{O}_{3}$ and $\mathrm{CO}$ at 7 stations are shown in Fig. 4. The agreement
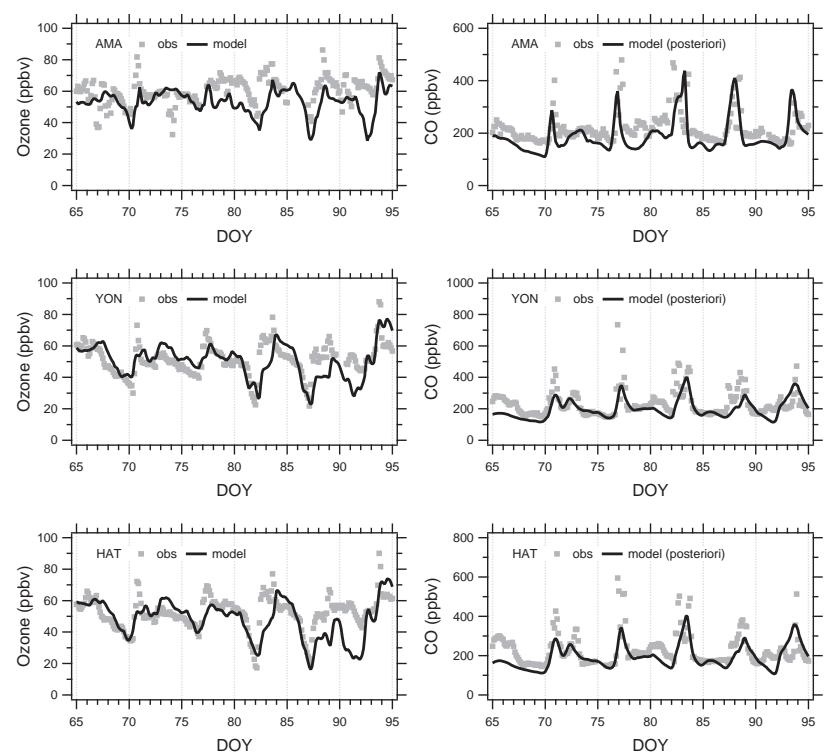

Fig. 3. Continued.

of the observed and modeled data for $\mathrm{O}_{3}$ is generally good in the range from 20 to $100 \mathrm{ppbv}$. A linear regression based on the reduced-major-axis (RMA) regression method gives a slope of $0.91 \pm 0.02$ and a near-zero intercept of $3.3 \pm 1.0$ ppbv for $\mathrm{O}_{3}$. For $\mathrm{CO}$, assimilated $\mathrm{CO}$ mixing ratios provide a relatively good positive correlation, with an overall slope of $0.85 \pm 0.03$ and a near-zero intercept of $3.4 \pm 3.8 \mathrm{ppbv}$ in the range of 150 to $600 \mathrm{ppbv}$. It should be noted that the model underestimated the observations in the high-CO regime, and overestimated in the low-CO regime, even after assimilations by the 4-dimensional adjoint inversion. This feature is consistent with the poor reproducibility of amplitude of the high pollution episodes shown in Fig. 3. The poor reproducibility at the high and low mixing ratios was likely due to problems associated with the horizontal resolution and the lateral boundary conditions employed in the model. The difficulty in simulating intense CO plumes over East Asia seems general challenges as reported by Kiley et al. (2003).

\section{Recent CO emissions from East Asia}

\subsection{A posteriori $\mathrm{CO}$ emissions in 2005}

By using continuous observations at six surface sites as constraints for East Asian CO emissions, we estimated CO emissions from East Asia for 2005. The spatial distribution of a posteriori $\mathrm{CO}$ emissions for 2005 inferred from the 4 dimensional adjoint inversion is shown in Fig. 5. Two regions clearly show strong emissions of $\mathrm{CO}$. One of the regions is located along the Chinese coastal zone from Beijing to Shanghai, and the other region is situated in the southeastern Asia around Thailand. Although the $\mathrm{CO}$ emissions 

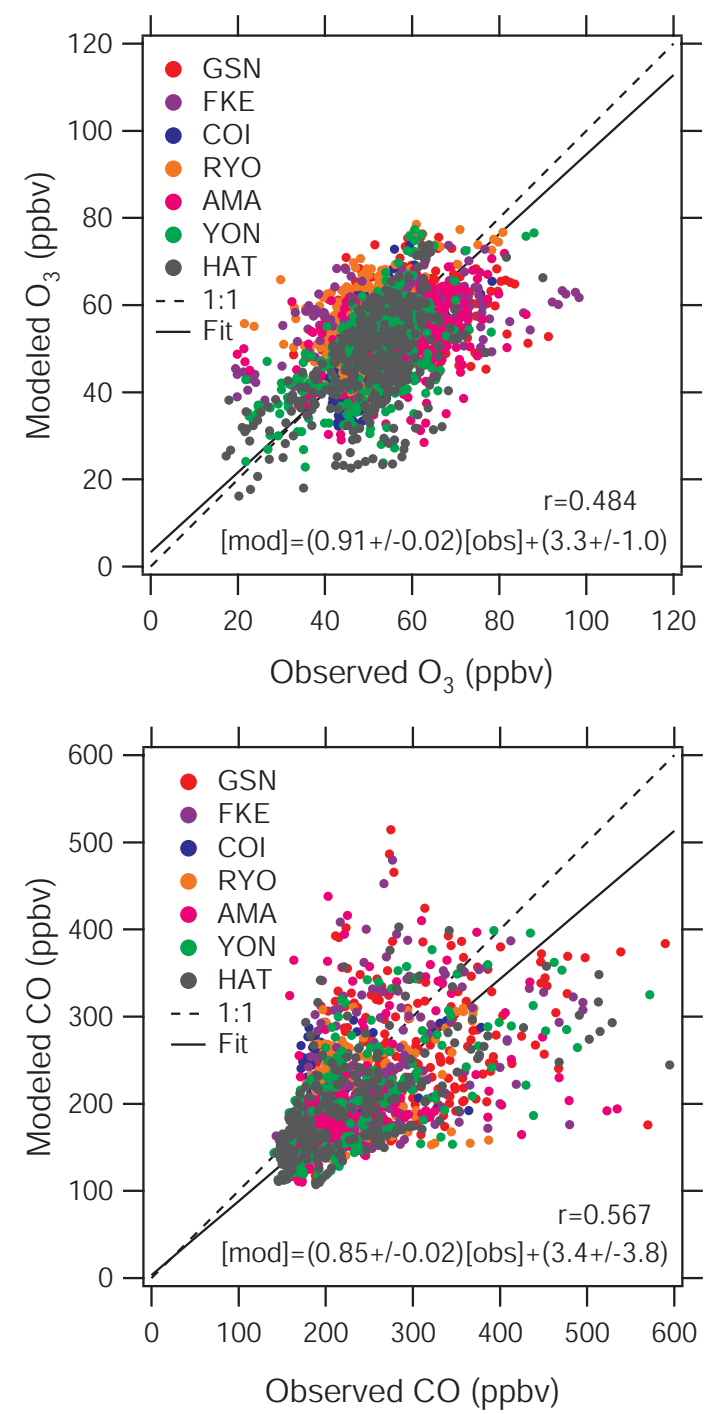

Fig. 4. Scatter plots of observed versus modeled mixing ratios of $\mathrm{O}_{3}$ (top panel) and $\mathrm{CO}$ (a posteriori, bottom panel) at seven stations. Both observed and modeled data are 3-hourly means. Data at Minamitorishima are not shown because it is outside the model domain. The regression lines (solid lines) are obtained by the reducedmajor-axis (RMA) regression method. The dashed lines depict 1:1 correspondence. Error limits of the slope and intercept represent $95 \%$ confidence levels.

from the southeastern Asia were stronger than those from China in 2005, the differences between a priori and a posteriori emissions are very small over the region. By contrast, the coastal zone in China, which is often called the Eastern Central China (ECC), exhibits areas of notable differences between a priori and a posteriori emissions, suggesting an increase in the $\mathrm{CO}$ emission from this region. Major emission sources are apparently Beijing and Shanghai, and these two mega-cities are significant contributors to that increase, as will be discussed below. a posteriori $\mathrm{CO}$ emission

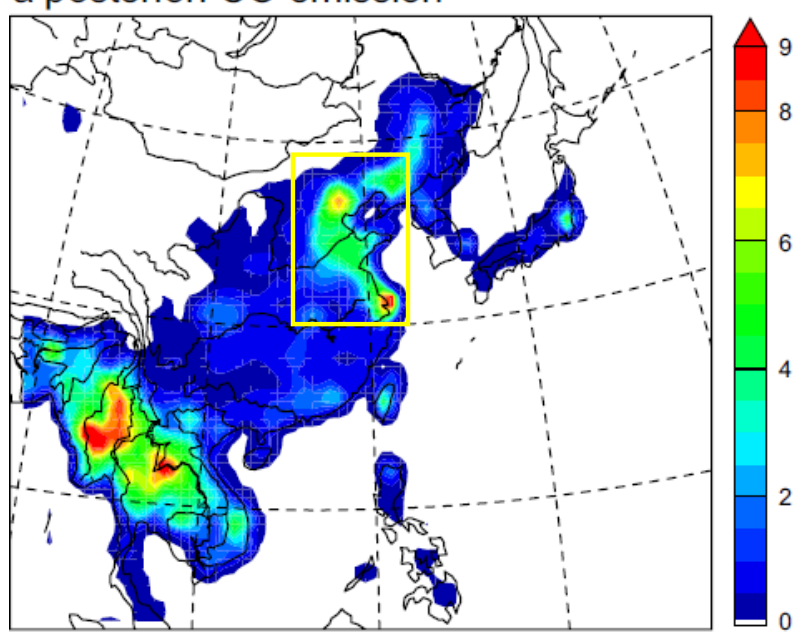

a posteriori - a priori

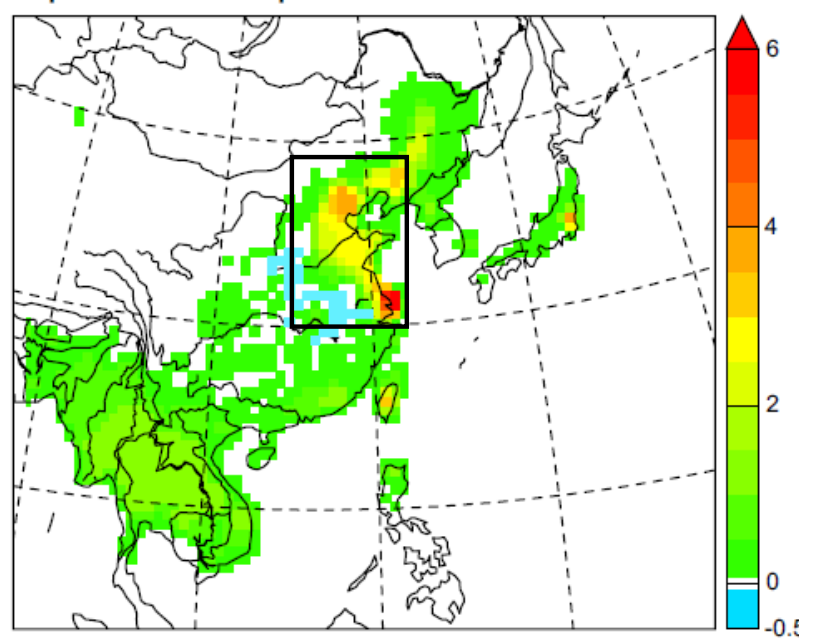

Fig. 5. Spatial distribution of a posteriori (upper panel) and the difference between a posteriori and a priori $\mathrm{CO}$ emissions (bottom panel) for 2005, as inferred from the adjoint inverse model. Unites are $\mu \mathrm{g} / \mathrm{m}^{2} / \mathrm{s}$. Box denotes Eastern Central China $\left(30-45^{\circ} \mathrm{N}, 113-\right.$ $\left.125^{\circ} \mathrm{E}\right)$.

\subsection{Growth in Chinese $\mathrm{CO}$ emissions}

Our inverse-model based estimates, along with the recent estimates for Chinese $\mathrm{CO}$ emissions by various methods, are summarized in Table 1. Two types of bottomup estimates are available since the year 2000. As already mentioned, Streets et al. (2006) have recently updated their previous estimates (Streets et al., 2003a) for Chinese anthropogenic emissions to $142 \mathrm{Tg}$, resulting in a total emission (including biomass burning) of $158 \mathrm{Tg}$ for the year 2001. More recently, Ohara et al. (2007) estimated the anthropogenic emission from China to be $137 \mathrm{Tg}$ for 2000 and $158 \mathrm{Tg}$ for 2003. Streets and coworkers developed an emission inventory for the INTEX-B 
Table 1. Comparison of recent estimates of Chinese $\mathrm{CO}$ emissions.

\begin{tabular}{|c|c|c|c|}
\hline \multirow[t]{2}{*}{ Study } & \multicolumn{2}{|c|}{ Chinese Emissions (Tg/year) } & \multirow[t]{2}{*}{ Year } \\
\hline & Anthropogenic & Biomass burning & \\
\hline \multicolumn{4}{|l|}{ Bottom-up Estimates } \\
\hline Streets et al. (2003a) & 100 & 16 & 2000 \\
\hline Streets et al. (2006) & 142 & 16 & 2001 \\
\hline Streets and Zhang (2007) & 167 & - & 2006 \\
\hline Ohara et al. (2007) & 137 & - & 2000 \\
\hline Ohara et al. (2007) & 158 & - & 2003 \\
\hline \multicolumn{4}{|l|}{ Inverse Model } \\
\hline Yumimoto and Uno (2006) & & $147^{*}$ & 2001 \\
\hline This work & & $170^{*}$ & 2005 \\
\hline Palmer et al. (2003) & $163-173$ & 12 & 2001 \\
\hline Pétron et al. (2004) & 132-194 & - & $2000-2001$ \\
\hline Arellano et al. (2004) & 195-222 & - & 2000 \\
\hline Wang et al. (2004) & & $166^{*}$ & 2001 \\
\hline Heald et al. (2004) & & $173^{*}$ & 2001 \\
\hline \multicolumn{4}{|l|}{ Forward Model } \\
\hline Allen et al. (2004) & $113-177$ & - & 2001 \\
\hline Carmichael et al. (2003) & 169-228 & - & 2001 \\
\hline
\end{tabular}

* Total emissions

campaign, and they estimated the Chinese anthropogenic emission for the year 2006 to be $167 \mathrm{Tg}$ (Streets and Zhang, manuscript in preparation, 2007, hereafter referred to as Streets and Zhang, 2007; also see http://www.cgrer.uiowa. edu/EMISSION_DATA_new/index_16.html).

In this study, our adjoint inversion method calculated $170 \mathrm{Tg}$ as the Chinese anthropogenic emission for the year 2005. Combined with the previous estimates by the same inversion method for the year 2001 (Yumimoto and Uno, 2006), we obtain an increase of $16 \%$ in the $\mathrm{CO}$ emission over the 5-year period (2001-2005). This is in a reasonable agreement with the estimate of $18 \%$ (2001-2006) calculated by Streets and Zhang (2007), and 15\% (2000-2003) by Ohara et al. (2007).

It should be noted that the previous top-down estimates of the $\mathrm{CO}$ emission from China showed substantial variability among the estimates, even for the same target year. This may result from differences in (1) observational data used to constrain emissions (e.g., locations, period, altitude, etc), (2) inversion techniques, (3) model types (e.g., resolution, meteorology, chemical schemes, etc), and (4) resolution of emissions data. Understanding the uncertainties arising from the different inversion approaches constitute a key issue in the assessment of the estimate accuracy, and will be addressed in future studies.

Figure 6 illustrates inter-annual variation in the annual CO emission from China estimated by our inversion technique for the year 2001 and 2005, as well as by the bottom-up methods, along with the CO column over ECC $\left(30-45^{\circ} \mathrm{N}\right.$, $113-125^{\circ} \mathrm{E}$ ) derived from the MOPITT (Measurements Of Pollution In The Troposphere) measurements. The MOPITT data were averaged only from austral winter to early spring (February-April), since the ECC region in this period is not affected by maritime air masses, which bring low-levels of $\mathrm{CO}$ in the lower troposphere over the region.

The REAS-based total emissions were further deconvoluted into contributions from domestic use, transportation, industry, and power plants for the period 2000 to 2003. $\mathrm{CO}$ emissions from the power plants were estimated to be very low since the combustion efficiency of power plants are usually high. Industrial and domestic usages were the two biggest anthropogenic emission sources, having almost equal contribution of $58 \pm 1 \mathrm{Tg} /$ year in 2000-2001. While the domestic contribution remained relatively steady, emissions from the industrial sector increased since 2002, reaching $73 \mathrm{Tg}$ in 2003. This increase contributed a dominant portion of about $76 \%$ (16 Tg out of the total of $21 \mathrm{Tg}$ ) to the overall change in the $\mathrm{CO}$ emission since 2000 . The increase in the $\mathrm{CO}$ emission from the industrial sector was due mainly to increased emissions from iron and steel factories. The transportation sector (mainly automobiles) contributed about $3 \mathrm{Tg}$ to the overall change due to an increase in traffic.

The MOPITT-derived CO columns over the ECC region showed a gradually increasing trend from 2001 to 2006 with 


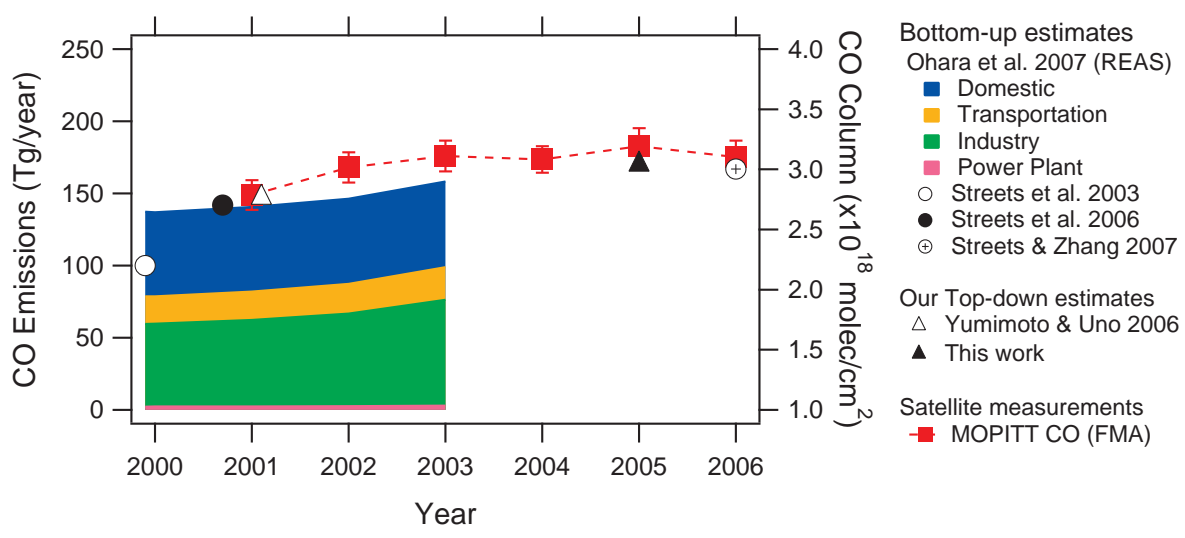

Fig. 6. Comparison of Chinese CO emissions derived from bottom-up and top-down estimates (left axis), and trends of MOPITT-derived CO column over Eastern Central China (right axis). The MOPITT data are averaged from austral winter to early spring (February-April). Error bars represent 1 standard deviations. Bottom-up estimates are only for anthropogenic emissions.

a slight inter-annual variation, indicating a $15 \%$ increase from 2001 to 2005. This result is in general agreement with the relative tendency of $\mathrm{CO}$ emissions estimated by the two bottom-up and our top-down approaches. The relatively small increase in the $\mathrm{CO}$ emission from China is in great contrast to the $\mathrm{NO}_{\mathrm{x}}$ emission, which shows a dramatic increase in recent years since 2000 (Ohara et al., 2007). While the domestic sector had the largest contribution in the 1990's, its contribution has been reduced as a result of the recent shift in energy usage for residential fuels, from biofuels and hard coal to cleaner energy such as oil and electricity. Compared to the early 1990's when the contribution from the domestic usage was at a maximum ( $\sim 75 \mathrm{Tg} /$ year $)$, its contribution decreased by $20 \%$ in 2003 . This reduction provides a significant offset to the recent growth in the industrial $\mathrm{CO}$ emission, resulting in a relatively small growth in the total $\mathrm{CO}$ emission since 2000 .

\section{Evolution of $\mathrm{O}_{3}$ in continental outflow}

\subsection{Observed $\mathrm{O}_{3}-\mathrm{CO}$ correlation}

The relative enhancement of $\mathrm{O}_{3}$ to $\mathrm{CO}$ (the $\Delta \mathrm{O}_{3} / \Delta \mathrm{CO}$ ratio) is often used as a diagnostic variable to evaluate photochemical $\mathrm{O}_{3}$ formation in pollution episodes. By using this diagnostic parameter, we examined how the $\mathrm{O}_{3}$-CO relationship evolved in continental pollution plumes from the Asian continent.

Figure 7 shows the absolute enhancements in $\mathrm{O}_{3}\left(\Delta \mathrm{O}_{3}\right)$ and $\mathrm{CO}(\Delta \mathrm{CO})$, as well as the $\Delta \mathrm{O}_{3} / \Delta \mathrm{CO}$ ratios as a function of transport time from the Asian continent to the downwind stations for the 3 pollution episodes (Events I to III). The $\Delta \mathrm{O}_{3}$ and $\Delta \mathrm{CO}$ values for each event were determined by "peak height", additional enhancement above the baseline level around the peak. The transport time from the Asian continent to the individual stations in the western North Pa- cific Rim were approximated by the observed time lags associated with advection of the $\mathrm{CO}$ peaks (associated with Events I to III) from Gosan to Fukuejima (1-5 h), to AmamiOshima (9-11 h), and to Yonagunijima/Hateruma (11-14 h). Comparatively, it took on average $60-102 \mathrm{~h}$ for a pollution event to travel from Gosan to Minamitorishima. It should be noted that these pollution events (Events I, II and III) were not clearly observed at the Ryori and Cape Ochi-ishi stations. Some plumes from the Asian continent do reach Ryori and Cape Ochi-ishi, but are affected by Japanese sources en route, and mixed influences from these sources have made clear and comparative analysis difficult, as noted in Sawa et al. (2007). Also polluted air masses transported from Gosan to northern Japan often traversed in the free troposphere, resulting in a very little correlational relationship between the measurements at Gosan and the surface air quality at Ryori and Cape Ochi-ishi.

The magnitude of enhanced CO peak measured at any one of the Japanese stations clearly depends on the transport time from Gosan. Although the magnitude of $\mathrm{CO}$ peaks observed at Gosan often exceeded 300 ppbv, they decayed quickly during the 3-4 days of eastward transport as the polluted air masses from the Asian continental sources mixed with relatively clean marine air. By contrast, the magnitude of high $\mathrm{O}_{3}$ episodes remained relatively constant at 10 to $30 \mathrm{ppbv}$ at all the sites. In fact, the $\mathrm{O}_{3}$ enhancement showed a slight increase during transport from Gosan to Minamitorishima. As shown in Fig. 2, the temporal variability of $\mathrm{O}_{3}$ is characteristically different from Event to Event, reflecting the roles various chemical processes play at different times in the production and destruction of $\mathrm{O}_{3}$. For a particular Event, the magnitude of the $\mathrm{O}_{3}$ enhancement, $\Delta \mathrm{O}_{3}$, remained not only relatively constant during its eastward transport, in spite of mixing with clean background maritime air, but showed some increase, unlike $\mathrm{CO}$, even though the lifetime of $\mathrm{O}_{3}$ is much shorter than $\mathrm{CO}$. The slight increase in $\Delta \mathrm{O}_{3}$ indicates 

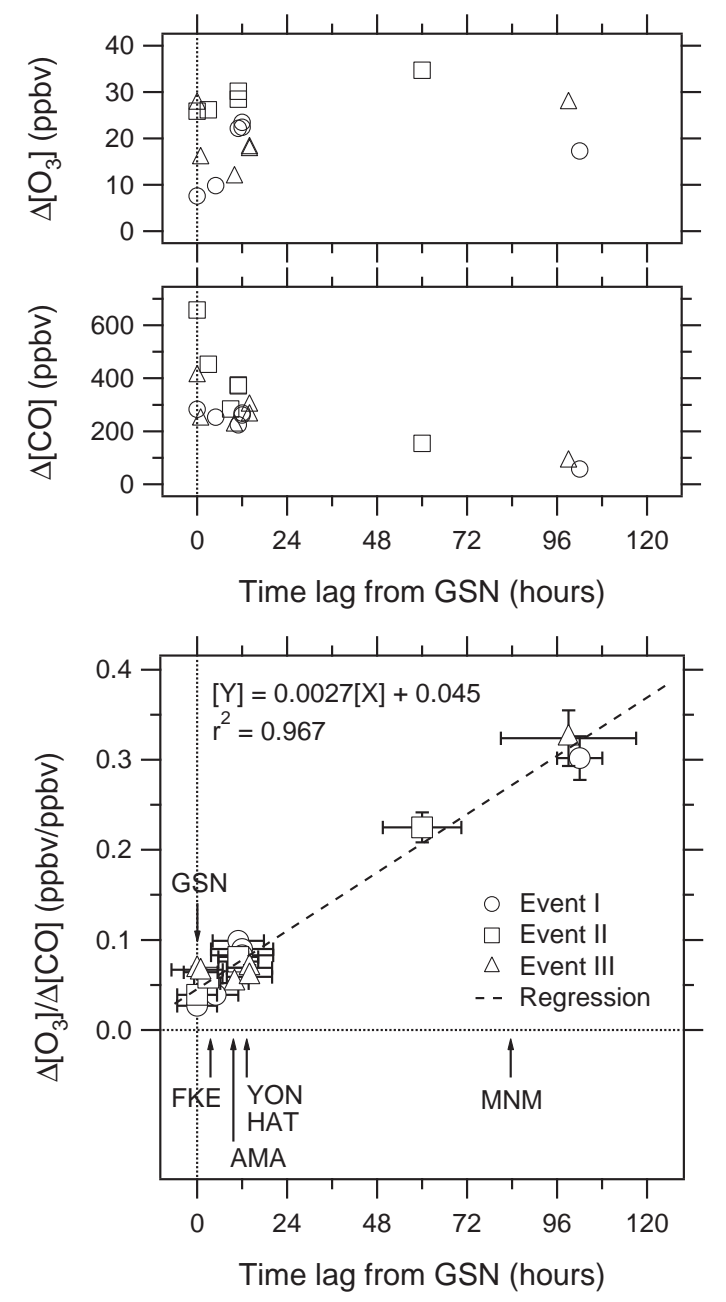

Fig. 7. Enhancement in $\mathrm{O}_{3}\left(\Delta \mathrm{O}_{3}\right)$, enhancement in $\mathrm{CO}(\Delta \mathrm{CO})$, and $\Delta \mathrm{O}_{3} / \Delta \mathrm{CO}$ ratios as a function of elapsed time from Gosan to other stations for the three pollution episodes. Error bars are based on the uncertainties in peak-width and regression analysis. Pollution Events I, II, and III are hatched in Fig. 2.

a net positive $\mathrm{O}_{3}$ production compensating the loss due to the dilution effects during transport.

The contrasting changes of $\mathrm{O}_{3}$ and $\mathrm{CO}$ as a function of transport time resulted in a clear variation in the $\Delta \mathrm{O}_{3} / \Delta \mathrm{CO}$ ratios at different stations. The $\Delta \mathrm{O}_{3} / \Delta \mathrm{CO}$ ratio at Gosan ranged from 0.03 to 0.07 . The ratio increased slightly to 0.05-0.1 after the 10-14 h of transport to Amami-Oshima, Yonagunijima, and Hateruma. At Minamitorishima, the ratio was significantly enhanced, ranging from 0.22 to 0.32 . Having minimized the influence of the dilution effect due to mixing with the background air during transport by taking the ratio of $\mathrm{O}_{3}$ to $\mathrm{CO}$, the increase in the $\Delta \mathrm{O}_{3} / \Delta \mathrm{CO}$ ratio is suggestive of the net $\mathrm{O}_{3}$ formation during the transport. It is to be noted that the several spike-like peaks observed near the source regions (i.e., Amami-Oshima, Yonagunijima, and Hateruma for Events II and III) could be "washed" into
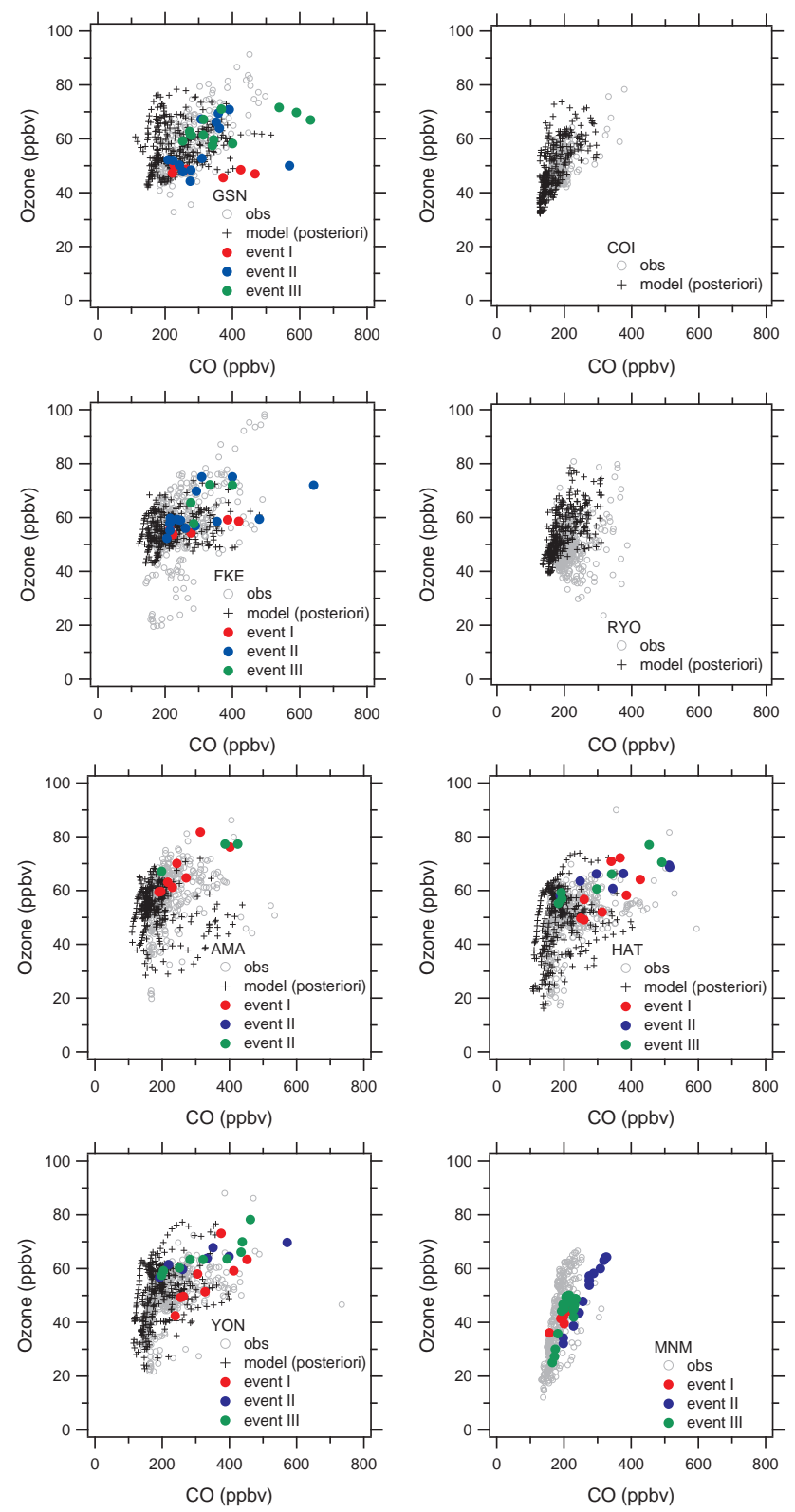

Fig. 8. Scatter plots of observed and modeled $\mathrm{O}_{3}$ versus $\mathrm{CO}$ mixing ratios at eight stations. Both observed and modelled values are 3hourly data. Observed data for the three pollution events (Events I, II, and III) are displayed by colored dots.

the broader peaks observed at Minamitorishima after the polluted air masses from different sources in China, Korea, and Japan were trapped and mixed, and then transported by cold fronts. Indeed, this could affect the absolute values of $\Delta \mathrm{O}_{3}$ or $\Delta \mathrm{CO}$. However, considering the similarity of the $\Delta \mathrm{O}_{3} / \Delta \mathrm{CO}$ ratios near the source regions, this mixing effect would cause little bias in the $\Delta \mathrm{O}_{3} / \Delta \mathrm{CO}$ ratios observed at Minamitorishima, and hence dependency on the transport time. 


\subsection{Modeled $\mathrm{O}_{3}-\mathrm{CO}$ correlation}

The monthly $\mathrm{O}_{3}-\mathrm{CO}$ correlation is not necessarily the same with the $\Delta \mathrm{O}_{3}-\Delta \mathrm{CO}$ correlation in pollution events, since the $\mathrm{O}_{3}$-CO correlation may become obscured by including different air mass types from continental to maritime air masses. However, the monthly $\mathrm{O}_{3}$-CO relationships (hereafter referred to as $\mathrm{O}_{3} / \mathrm{CO}$ ratios) still provide a valuable test for model predictions of anthropogenic influence on $\mathrm{O}_{3}$, particularly if the period of interest is dominated by specific meteorological conditions. This would be the case for spring season in East Asia since synoptic-scale transport basically dictates regional spatial patterns and temporal variability of trace gases such as $\mathrm{CO}$ and $\mathrm{O}_{3}$. Figure 8 shows scatter plots of observed and modeled $\mathrm{O}_{3}$ versus $\mathrm{CO}$ mixing ratios at the 8 stations. The plots show a general positive correlation between $\mathrm{O}_{3}$ and $\mathrm{CO}$ at all the stations. Although the model failed to reproduce groups of several high $\mathrm{O}_{3}$ and $\mathrm{CO}$ peaks, the overall monthly relationships between $\mathrm{O}_{3}$ and $\mathrm{CO}$ were reasonably well simulated. The model showed relatively poor reproducibility in predicting high $\mathrm{O}_{3}$ and $\mathrm{CO}$ data clusters, as was indicated in Figs. 3 and 4. This could have been caused by the limited horizontal $(80 \mathrm{~km})$ resolution used in the model; it is also possible that the model did not contain all the relevant $\mathrm{CO}$ emissions. Episodes of low $\mathrm{O}_{3}$ associated with high $\mathrm{CO}$ observed at Ryori and Fukuejima were not well reproduced by the model, likely due to the sub-grid scale titration of $\mathrm{O}_{3}$ with $\mathrm{NO}$ by local pollution sources around these sites. However, the overall general nature of the $\mathrm{O}_{3}-\mathrm{CO}$ correlation was well simulated, suggesting that the mean salient features of the $\mathrm{O}_{3}-\mathrm{CO}$ variability affected by the synoptic-scale transport of pollutants were fairly well reproduced in the model. Better positive correlation and lesser scatters at Cape Ochi-ishi than at Gosan, Amami-Oshima, Hateruma, and Yonagunijima are likely because the surface level of northern Japan is less directly influenced by East Asian outflow. The observed $\mathrm{O}_{3}-\mathrm{CO}$ correlation at Minamitorishima is more bounded than those at the other stations closer to the continent, suggesting that the air masses arriving at Minamitorishima were "well-aged" and negligibly perturbed by surface sources during transport over the ocean from the continental source regions. The $\mathrm{O}_{3}-\mathrm{CO}$ correlation at Minamitorishima shows a steeper slope, but the absolute $\mathrm{O}_{3}$ levels are not as high as those observed at the other stations as a result of mixing with clean maritime air masses.

The geographical distribution of the $\mathrm{O}_{3} / \mathrm{CO}$ ratio for March 2005 calculated by the model is shown in Fig. 9. Assimilated CO data were used. The pattern over East Asia in particular is in good quantitative agreement with the results from a previous global model study (Mauzerall et al., 2000). Values of the ratio less than 0.1 (but greater than zero) are located near the Asian continent, increasing to more than 0.5 over the Pacific Ocean. Compared to the observed values at Minamitorishima, the latter is an overestimate, possibly

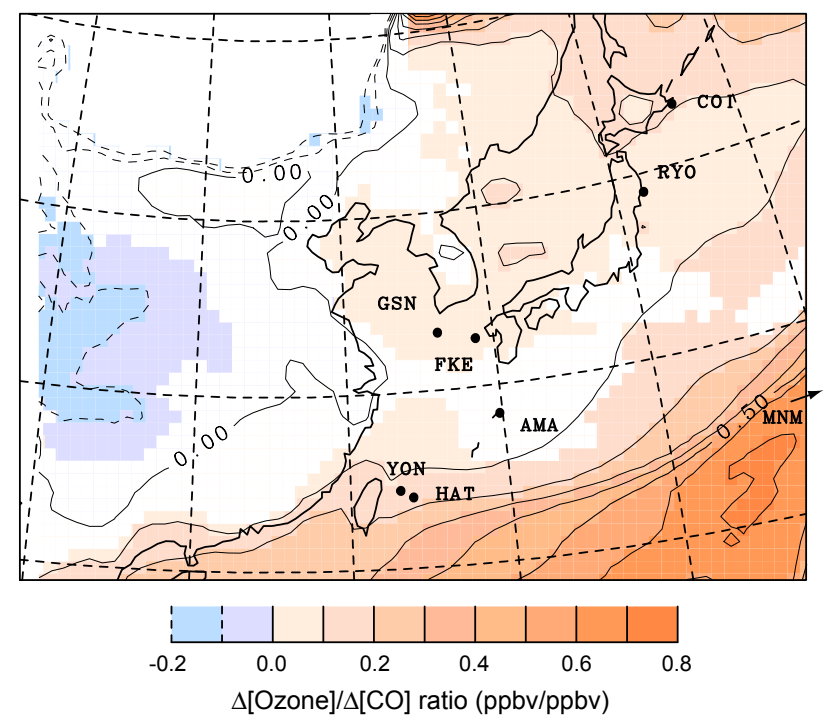

Fig. 9. Spatial distribution of simulated $\mathrm{O}_{3} / \mathrm{CO}$ ratios for March 2005. Assimilated CO data are used. Locations of the stations are also plotted. The arrow (bottom-right corner) indicates the location of Minamitorishima (MNM). The regions where correlation coefficient is less than 0.3 are shown in white.

reflecting boundary conditions in the model. Near-zero or even negative $\mathrm{O}_{3} / \mathrm{CO}$ ratios over and near the source regions are likely due to large short-term variability in $\mathrm{CO}$ emitted by the surface sources. Large perturbations in $\mathrm{CO}$ emissions also result in poor statistical significance around that region. These features suggest that not only photochemistry but also meteorological factors (e.g., mixing of different origin of air masses and dilution with background air) play a key role in controlling monthly mean $\mathrm{O}_{3} / \mathrm{CO}$ ratios in this region.

\subsection{Comparison with other studies}

Zhang et al. (2006) recently showed strong positive $\mathrm{O}_{3} / \mathrm{CO}$ correlations in the middle troposphere downwind of continental source regions such as East Asia, by utilizing the Tropospheric Emission Spectrometer (TES) observations. Based on aircraft observations, Kondo et al. (2004) showed that a net $\mathrm{O}_{3}$ production occurred in the marine boundary layer at the mid-latitude region (in particular $30^{\circ} \mathrm{N}-45^{\circ} \mathrm{N}$ ) over the western Pacific in the spring of 2001, due to relatively high NO levels combined with strong westerly advection during this season. The net $\mathrm{O}_{3}$ production was also positive in the upper troposphere due to high $\mathrm{NO}$ and low $\mathrm{H}_{2} \mathrm{O}$ levels. These results add to the support of the $\mathrm{O}_{3}-\mathrm{CO}$ correlations reported in the present work and by Zhang et al. (2006), confirming that East Asia is an important $\mathrm{O}_{3}$ source region during spring.

Liang et al. (2004) found that a majority of trans-Pacific transport events of Asian pollution reaching the northeast $\mathrm{Pa}-$ cific below $2 \mathrm{~km}$ altitude was caused by advection in the marine boundary layer associated with cold fronts. We have 
found that the polluted air masses are initially trapped in the boundary layer over Asia before being transported to the Pacific Ocean by cold fronts. They also attributed several elevated CO peaks observed at Minamitorishima to longrange transport in the boundary layer of Asian $\mathrm{CO}$, based on tagged tracer experiments. Price et al. (2004) analyzed photochemical evolution of $\mathrm{O}_{3}$ in air masses transported from Asia to the northwest United States, based on the ratio of excess $\mathrm{O}_{3}$ to excess $\mathrm{CO}$ observed at Cheeka Peak Observatory (CPO) and by aircraft measurements. They obtained values of $\Delta \mathrm{O}_{3} / \Delta \mathrm{CO}$ ranging from -0.06 to 1.52 . They also found that $\Delta \mathrm{O}_{3} / \Delta \mathrm{CO}$ ranged from 0.1 to 0.5 in pollution plumes (mainly from combustion sources such as industrial and/or biomass burning) transported in layers $2-5 \mathrm{~km}$ high. Plumes with lower $\Delta \mathrm{O}_{3} / \Delta C \mathrm{C}$ values $(<0.10)$ were characteristic of long-range transport in the boundary layer or of an environment with substantial presence of mineral dust. The lower $\Delta \mathrm{O}_{3} / \Delta \mathrm{CO}$ ratios likely resulted from shorter lifetime of $\mathrm{O}_{3}$ at lower altitude and/or heterogeneous reaction associated with sea salt or dust aerosols. The $\Delta \mathrm{O}_{3} / \Delta \mathrm{CO}$ ratios observed at Minamitorishima, ranging from 0.2 to 0.35 , are in a good agreement with those observed in trans-Pacific plumes of combustion origins, but significantly higher than those observed in the plumes reaching the northwest United States. One possible explanation for this is that the net photochemical production of $\mathrm{O}_{3}$ is active during the first 3-4 days of the boundary layer transport after leaving the pollution sources in Asia, but the production decreases thereafter due to very low NO levels over remote Pacific Ocean, showing noticeably lower values of $\Delta \mathrm{O}_{3} / \Delta \mathrm{CO}$ by the time the pollution plume reaches west coast of the United States.

\section{Concluding remarks}

We coordinated simultaneous observations of $\mathrm{O}_{3}$ and $\mathrm{CO}$ at 8 surface sites located in the East Asia Pacific Rim from $24^{\circ} \mathrm{N}$ to $43^{\circ} \mathrm{N}$ during March 2005 when continental outflow plays a dominant role in transporting air pollutants from East Asia to the Pacific Ocean. We analyzed these continuous data using a 3-dimensional regional chemistry transport model, to diagnose recent changes in $\mathrm{CO}$ emissions from East Asia and photochemical evolution of $\mathrm{O}_{3}$ in air masses transported in the marine boundary layer exported from the Asian continent. From the hourly data, three major pollution episodes were selected for detailed analyses since these episodic events were well characterized by Sawa et al. (2007).

A 4-dimensional adjoint inverse model was first used to improve CO emissions from East Asia for the year 2005, constrained by highly time-resolved continuous measurements at the 6 surface sites. With the a posteriori $\mathrm{CO}$ emissions inventory, the model was able to reproduce observed levels and temporal variations of $\mathrm{O}_{3}$ and $\mathrm{CO}$ fairly well. The inversion analysis indicated an annual anthropogenic $\mathrm{CO}$ emission of about $170 \mathrm{Tg}$ from China in 2005, a $16 \%$ increase since 2001 (based on the same inverse model used in this study). These emission estimates are in good agreement with those obtained by two bottom-up approaches, as well as with the recent changes derived from MOPITT satellite observations of $\mathrm{CO}$ column over the industrial regions in China.

We also performed various analyses of the $\mathrm{O}_{3}-\mathrm{CO}$ relationship as a function of transport time from the source regions to the monitoring sites for 3 major pollution events observed at all the stations and denoted as Events I, II and III. The $\Delta \mathrm{O}_{3} / \Delta \mathrm{CO}$ ratios increased with age of the polluted air masses over the course of 3-4 days from the source regions. It is suggested that en-route photochemical $\mathrm{O}_{3}$ formation occurred during pollution transport events from the Asian continent to the western North Pacific, and that this region is an important source for tropospheric $\mathrm{O}_{3}$ during spring.

Acknowledgements. We thank Jae Cheol Nam, So Young Bang, Changbum Cho at Meteorological Research Institute, Korean Meteorological Administration, Kyung-Ryul Kim at Seoul National University, and Gangwoong Lee at Hankuk University of Foreign Studies for logistical support at Gosan. This study was financially supported by Global Environmental Research Fund of the Ministry of the Environment, Japan (FS-11). The $\mathrm{CO}$ and $\mathrm{O}_{3}$ data observed at Ryori, Yonagunijima and Minamitorishima were taken from the WDCGG. Many thanks go to Kaz Higuchi for valuable comments on the manuscript. H. T. acknowledges Daniel Jacob at Harvard University for the use of the Harvard resources in MOPITT data analysis.

Edited by: P. Monks

\section{References}

Akimoto, H.: Global air quality and pollution, Science, 302, 17161719, 2003.

Akimoto, H., Ohara, T., Kurokawa, J., and Horii, N.: Verification of energy consumption in China during 1996-2003 by satellite observation, Atmos. Environ., 40, 7663-7667, 2006.

Allen, D., Pickering, K., and Fox-Rabinovitz, M.: Evaluation of pollutant outflow and $\mathrm{CO}$ sources during TRACE-P using modelcalculated, aircraft-based, and Measurements Of Pollution In The Troposphere (MOPITT)-derived CO concentrations, J. Geophys. Res., 109, D15S03, doi:10.1029/2003JD004250, 2004.

Arellano, A. F., Kasibhatla, P. S., Giglio, L., van der Werf, G. R., and Randerson, J. T.: Top-down estimates of global CO sources using MOPITT measurements, Geophys. Res. Lett., 31(1), L01104, doi:10.1029/2003GL018609, 2004.

Carmichael, G. R., Tang, Y., Kurata, G., Uno, I., Streets, D. G., Thongboonchoo, N., Woo, J.-H., Guttikunda, S., White, A., Wang, T., Blake, D. R., Atlas, E., Fried, A., Potter, B., Avery, M. A., Sachse, G. W., Sandholm, S. T., Kondo, Y., Talbot, R. W., Bandy, A., Thorton, D., and Clarke, A. D.: Evaluating regional emissions estimates using the TRACE-P observations, J. Geophys. Res., 108(D21), 8810, doi:10.1029/2002JD003116, 2003.

Heald, C. H., Jacob, D. J., Jones, D. B. A., Palmer, P. I., Logan, J. A., Streets, D. G., Sachse, G. W., Gille, J. C., Hoffman, R. N., 
and Nehrkorn, T.: Comparative inverse analysis of satellite (MOPITT) and aircraft (TRACE-P) observations to estimate Asian sources of carbon monoxide, J. Geophys. Res., 109, D23306, doi:10.1029/2004JD005185, 2004.

Jacob, D. J., Crawford, J. H., Kleb, M. M., Connors, V. S., Bendura, R. J., Raper, J. L., Sachse, G. W., Gille, J. C., Emmons, L., and Heald, C. L.: Transport and Chemical Evolution over the Pacific (TRACE-P) aircraft mission: Design, execution, and first results, J. Geophys. Res., 108(D20), 9000, doi:10.1029/2002JD003276, 2003.

Kiley, C. M., Fuelberg, H. E., Palmer, P. I., Allen, D. J., Carmichael, G. R., Jacob, D. J., Mari, C., Pierce, R. B., Pickering, K. E., Tang, Y., Wild, O., Fairlie, T. D., Logan, J. A., Sachse, G. W., Shaack, T. K., and Streets, D. G.: An intercomparison and evaluation of aircraft-derived and simulated CO from seven chemical transport models during the TRACE-P experiment, J. Geophys. Res., 108(D21), 8819, doi:10.1029/2002JD003089, 2003.

Kondo, Y., Nakamura, K., Chen, G., Takegawa, N., Koike, M., Miyazaki, Y., Kita, K., Crawford, J., Ko, M., Blake, D. R., Kawakami, S., Shirai, T., Liley, B., Wang, Y., and Ogawa, T.: Photochemistry of ozone over the western Pacific from winter to spring, J. Geophys. Res., 109, D23S02, doi:10.1029/2004JD004871, 2004.

Liang, Q., Jaeglé, L., Jaffe, D. A., Weiss-Penzias, P., Heckman, A., and Snow, J. A.: Long-range transport of Asian pollution to the northeast Pacific: Seasonal variations and transport pathways of carbon monoxide, J. Geophys. Res., 109, D23S07, doi:10.1029/2003JD004402, 2004.

Matsueda, H., Inoue, H. Y., Sawa, Y., and Tsutsumi, Y.: Carbon monoxide in the upper troposphere over the western Pacific between 1993 and 1996, J. Geophys. Res., 103(D15), 19093$19110,1998$.

Mauzerall, D. L., Narita, D., Akimoto, H., Horowitz, L., Walters, S., Hauglustaine, D. A., and Brasseur, G.: Seasonal characteristics of tropospheric ozone production and mixing ratios over East Asia: A global three-dimensional chemical transport model analysis, J. Geophys. Res., 105, 17 895-17 910, 2000.

Ohara, T., Akimoto, H., Kurokawa, J., Horii, N., Yamaji, K., Yan, X., and Hayasaka, T.: An Asian emission inventory of anthropogenic emission sources for the period 1980-2020, Atmos. Chem. Phys., 7, 4419-4444, 2007, http://www.atmos-chem-phys.net/7/4419/2007/.

Palmer, P. I., Jacob, D. J., Jones, D. B. A., Heald, C. L., Yantosca, R. M., Logan, J. A., Sachse, G. W., and Streets, D. G.: Inverting for emissions of carbon monoxide from Asia using aircraft observations over the western Pacific, J. Geophys. Res., 108(D21), 8828, doi:10.1029/2003JD003397, 2003.

Parrish, D. D., Holloway, J. S., Trainer, M., Murphy, P. C., Forbes, G. L., and Fehsenfeld, F. C.: Export of North American ozone pollution to the North Atlantic Ocean, Science, 259, 1436-1439, 1993.

Parrish, D. D., Trainer, M., Holloway, J. S., Yee, J. E., Warshawsky, M. S., Fehsenfeld, F. C., Forbes, G. L., and Moody, J. L.: Relationships between ozone and carbon monoxide at surface sites in the North Atlantic region, J. Geophys. Res., 103, 13 357-13 376, 1998.

Pétron, G., Granier, C., Khattatov, B., Yudin, V., Lamarque, J.-F., Emmons, L., Gille, J., and Edwards, D. P.: Monthly CO surface sources inventory based on the 2000-2001 MO-
PITT satellite data, Geophys. Res. Lett., 31(21), L21107, doi:10.1029/2004GL020560, 2004.

Pielke, R. A., Cotton, W. R., Walko, R. L., Tremback, C. J., Lyons, W. A., Grasso, L. D., Nicholls, M. E., Moran, M. D., Wesley, D. A., Lee, T. J., and Copeland, J. H.: A comprehensive meteorological modeling system: RAMS, Meteor. Atmos. Phys., 49, 69-91, 1992.

Price, H. U., Jaffe, D. A., Cooper, O. R., and Doskey, P. V.: Photochemistry, ozone production, and dilution during long-range transport episodes from Eurasia to the northwest United States, J. Geophys. Res., 109, D23S13, doi:10.1029/2003JD004400, 2004.

Richter, A., Burrows, J. P., Nuss, H., Granier, C., and Niemeier, U.: Increase in tropospheric nitrogen dioxide over China observed from space, Nature, 437, 129-132, 2005.

Sawa, Y., Tanimoto, H., Yonemura, S., Matsueda, H., Wada, A, Taguchi, S., Hayasaka, T., Tsuruta, H., Tohjima, Y., Mukai, H., Kikuchi, N., Katagiri, S., and Tsuboi, K.: Widespread pollution events of carbon monoxide observed over the western North Pacific during the East Asian Regional Experiment (EAREX) 2005 campaign, J. Geophys. Res., 112, D22S26, doi:10.1029/2006JD008055, 2007.

Streets D. G., Bond, T. C., Carmichael, G. R., Fernandes, S. D., Fu, Q., He, D., Klimont, Z., Nelson, S. M., Tsai, N. Y., Wand, M. Q., Woo, J.-H., and Yarber, K. F.: An inventory of gaseous and primary aerosol emissions in Asia in the year 2000. J. Geophys. Res., 108(D21), 8809, doi:10.1029/2002JD003093, 2003a.

Streets, D. G., Yarber, K. F., Woo, J.-H., and Carmichael, G. R.: Biomass burning in Asia: Annual and seasonal estimates and atmospheric emissions, Global Biogeochem. Cy., 17(4), 1099, doi:10.1029/2003GB002040, 2003 b.

Streets, D. G., Zhang, Q., Wang, L. He, K., Hao, J., Wu, Y., Tang, Y., and Carmichael, G. R.: Revisiting China's CO emissions after the Transport and Chemical Evolution over the Pacific (TRACE-P) mission: Synthesis of inventories, atmospheric modeling, and observations, J. Geophys. Res., 111, D14306, doi:10.1029/2006JD007118, 2006.

Tanimoto, H., Sawa, Y., Matsueda, H., Uno, I., Ohara, T., Yamaji, K., Kurokawa, J., and Yonemura, S.: Significant latitudinal gradient in the surface ozone spring maximum over East Asia, Geophys. Res. Lett., 32, L21805, doi:10.1029/2005GL023514, 2005.

Tanimoto, H., Mukai, H., Hashimoto, S., and Norris, J. E.: Intercomparison of ultraviolet photometry and gas-phase titration techniques for ozone reference standards at ambient levels, J. Geophys. Res., 111, D16313, doi:10.1029/2005JD006983, 2006.

Tanimoto, H., Mukai, H., Sawa, Y., Matsueda, H., Yonemura, S., Wang, T., Poon, S., Wong, A., Lee, G., Jung, J. Y., Kim, K. R., Lee, M. H., Lin, N. H., Wang, J. L., Ou-Yang, C. F., Wu, C. F., Akimoto, H., Pochanart, P., Tsuboi, K. Doi, H., Zellweger, C., and Klausen, J.: Direct assessment of international consistency of standards for ground-level ozone: Strategy and implementation toward metrological traceability network in Asia, J. Environ. Monit., 9, 1183-1193, doi:10.1039/b701230f, 2007a.

Tanimoto, H., Sawa, Y., Matsueda, H., Wada, A., Yonemura, S., Mukai, H., Wang, T., Poon, S., Wong, A., Lee, G., Jung, J. Y., Kim, K. R., Lee, M. H., Lin, N. H., Wang, J. L., Ou-Yang, C. F., and Wu, C. F.: Evaluation of standards and methods for continuous measurements of carbon monoxide at ground-based sites in Asia, Pap. Met. Geophys., 58, 85-93, 
doi:10.2467/mripapers.58.85, 2007b.

Tohjima, Y., Machida, T., Utiyama, M., Katsumoto, M., Fujinuma, Y., and Maksyutov, S.: Analysis and presentation of in situ atmospheric methane measurements from Cape Ochiishi and Hateruma Island, J. Geophys. Res., 107(D12), 4148, doi:10.1029/2001JD001003, 2002.

Uno I., He, Y., Ohara, T., Yamaji, K., Kurokawa, J.-I., Katayama, M., Wang, Z., Noguchi, K., Hayashida, S., Richter, A., and Burrows, J. P.: Systematic analysis of interannual and seasonal variations of model-simulated tropospheric $\mathrm{NO}_{2}$ in Asia and comparison with GOME-satellite data, Atmos. Chem. Phys., 7, 16711681, 2007, http://www.atmos-chem-phys.net/7/1671/2007/.

Wang, Y. X., McElroy, M. B., Wang, T., and Palmer, P. I.: Asian emissions of $\mathrm{CO}$ and $\mathrm{NO}_{\mathrm{X}}$ : Constraints from aircraft and Chinese station data, J. Geophys. Res., 109, D24304, doi:10.1029/2004JD005250, 2004.

Watanabe, F., Uchino, O., Joo, Y., Aono, M., Higashijima, K., Hirano, Y., Tsuboi, K., and Suda, K.: Interannual variation of growth rate of atmospheric carbon dioxide concentration observed at the JMA's three monitoring stations: Large increase in concentration of atmospheric carbon dioxide in 1998, J. Meteorol. Soc. Jpn., 78, 673-682, 2000.
Wong, H. L. A., Wang, T., Ding, A., Blake, D. R., and Nam, J. C.: Impact of Asian continental outflow on the concentrations of $\mathrm{O}_{3}, \mathrm{CO}$, NMHCs and halocarbons on Jeju Island, South Korea during March 2005, Atmos. Environ., 41, 2933-2944, doi:10.1016/j.atmosenv.2006.12.030, 2007.

Yumimoto, K. and Uno, I.: Adjoint inverse modeling of CO emissions over the East Asian region using four dimensional variational data assimilation, Atmos. Environ., 40, 6836-6845, 2006.

Yumimoto, K., Uno, I., Sugimoto, N., Shimizu, A., and Satake, S.: Adjoint inverse modeling of dust emission and transport over East Asia, Geophys. Res. Lett., 34, L08806, doi:10.1029/2006GL028551, 2007.

Zellweger, C., Klausen, J., and Buchmann, B.: System and Performance Audit for Surface Ozone, Carbon Monoxide and Methane at JMA GAW Facilities, Part A: Regional GAW station Ryori, Japan, November 2005, WCC-Empa Report 05/4 - Part A., 40 pp., Empa Dübendorf, Switzerland, 2005.

Zhang, L., Jacob, D. J., Bowman, K. W., Logan, J. A., Turquety, S., Hudman, R. C., Li, Q., Beer, R., Worden, H. M., Worden, J. R., Rinsland, C. P., Kulawik, S. S., Lampel, M. C., Shephard, M. W., Fisher, B. M., Eldering, A., and Avery, M. A.: OzoneCO correlations determined by the TES satellite instrument in continental outflow regions, Geophys. Res. Lett., 33, L18804, doi:10.1029/2006GL026399, 2006. 